\title{
Donation and waiting list for corneal transplantation in the State of Rio de Janeiro
}

\author{
Doação e fila de transplante de córnea \\ no Estado do Rio de Janeiro
}

Gustavo Bonfadini ${ }^{1}$, Victor Roisman'1, Rafael Prinz², Rodrigo Sarlo³, Eduardo Rocha ${ }^{4}$, Mauro Campos ${ }^{5}$

\begin{abstract}
This paper aims to describe the process of organ and tissue donation, tissue harvesting, queue and transplants as a health policy in Brazil and in the State of Rio de Janeiro, with emphasis on procedures for corneal transplantation. The low reporting of possible donors associated with a high rate of negative family in donation, associated with the insufficient number of corneas provided by Eye Banks are the main factors limiting the increase in the number of corneal transplants in Brazil. The creation of the Rio de Janeiro Eye Bank associated with policies that encourage increased reporting and collection of corneas aims to reduce the waiting list for corneal transplantation in Rio de Janeiro State.
\end{abstract}

Keywords: Cornea; Corneal transplantation; Eye bank; Waiting lists; Tissue donors; Keratoplasty; Health management

\section{Resumo}

O presente trabalho objetiva descrever o processo de doação, captação, fila de espera e transplante de órgãos e tecidos como uma das políticas de saúde no Brasil e no Estado do Rio de Janeiro, com ênfase nos procedimentos relativos aos transplantes de córnea. A baixa notificação de possíveis doadores e a alta taxa de negativa familiar na doação associado ao insuficiente número de córneas disponibilizadas por Banco de Olhos são os principais fatores que limitam o aumento do número dos transplantes de córnea no Brasil. A criação do Banco de Olhos do Rio de Janeiro, associado a politicas que estimulam o aumento da notificação e captação de córneas visa diminuir a fila de espera para transplante de córnea no Estado.

Descritores: Córnea; Transplante de córnea; Banco de olhos; Listas de espera; Doadores de tecidos, Ceratoplastia; Gestão em saúde

\footnotetext{
${ }^{1}$ Rio de Janeiro Eye Bank, INTO, Rio de Janeiro/RJ, Brazil.

${ }^{2}$ Multi-tissue Transplant Unit, INTO, Rio de Janeiro/RJ, Brazil.

${ }^{3}$ State Transplant Programme, Rio de Janeiro/RJ, Brazil.

${ }^{4}$ Federal University of Rio de Janeiro, Rio de Janeiro/RJ, Brazil.

${ }^{5}$ Federal University of São Paulo, São Paulo/SP, Brazil.
}

The authors declare no conflict of interest. 


\section{INTRODUCTION}

C orneal diseases are the second leading cause of reversible blindness worldwide. Corneal transplantation is procedure. ${ }^{1}$

currently the most successful and most common transplant

The census performed by the Brazilian Institute of Geography and Statistics (IBGE) in $2010^{2}$ found that visual impairment is the most commonly reported disability in Brazil, affecting with 35.7 million Brazilians (from a population of 190 million people). Corneal diseases are a major cause of vision loss, producing psychological and economic consequences for the individual and society as a whole. ${ }^{3}$

Brazil has the largest public transplant system in the world, having performed 15,281 corneal transplants in 2012 with an estimated yearly demand for 17,168 translpalnts. ${ }^{4}$ In October 2013 the national waiting list for corneal transplants for visual rehabilitation in Brazil had 7,245 patients. ${ }^{5}$

The state of Rio de Janeiro has the second largest national Gross Domestic Product (GDP) in the country and an estimated population of $15,993,583$ people. $^{6}$

In November 2013 the transplant waiting list in Rio de Janeiro had 823 patients, or about 52 per million population (pmp).

This paper reviews the legislation, aspects eye tissue donation, harvesting and distribution process, and the waiting list for corneal transplants in the state of Rio de Janeiro.

Legal framework and structure of the organ and tissue transplantation policy in Brazil

\section{Registering in the corneal transplant waiting list:}

For a patient to be registered, he/she should seek or be referred to a transplant team accredited by the Ministry of Health that will represent and register him/her at the management information system (SIG) coordinated by the national transplant system (SNT). This generates a registration number known as general technical record (RGCT). This number is very important as it identifies the patient in a single registry that contains data such as the patient's situation on the waiting list, among other information.

Distribution of corneas: The distribution of corneas and other eye tissues is made by the each state's Organ Notification, Collection and Distribution Unit (CNCDO). Each state has a unique waiting list for corneal transplantation based on the time of registration of each patient, as determined in Ordinance GM 3407 of August 5, 1998. This ordinance also establishes urgency criteria, i.e. situations where tissue distribution is prioritised. They include: 1) perforation of the eye globe; 2) imminent corneal perforation, descemetocele; 3) recipient under 7 years of age with bilateral corneal opacity; 4) corneal ulcer unresponsive to medical treatment; 5) primary failure within 90 days of transplantation with a viable cornea for optical transplant. Other cases need to be evaluated and approved by the state's technical council for corneal transplantation.

It should be noted that in priority situations the recipient's corneal button needs to be submitted to the eye bank that offered the tissue. The eye bank is responsible for submitting the tissue to histopathological examination to confirm the diagnosis.

\section{Legal framework:}

Procurement of organs and tissues for transplantation in Brazil is regulated by Law 9434/97, known as the Transplant Law, which deals with legal issues related to the removal of organs, tissues and body parts for transplantation and treatment and establishes the criminal and administrative sanctions for violations of the law. Decree-Law 2268/97 created the SNT and CNCDOs in all Brazilian states, decentralising the organ donation and transplantation process and establishing presumed consent for organ and tissue donation.

The CNCDOs or "transplant centrals" are the executive units for SNT activities, responsible for coordinating transplant activities; registering potential recipients with all necessary information for quickly locating them and verifying their compatibility for organ/tissue transplantation or grafting; classifying recipients, ordering them according to the date of registration, and providing them with a confirmation document; communicating registrations to the SNT in order to organise the national waiting list; receiving death notifications; and forwarding and transporting organs and tissues to authorised health facilities where the ideal recipient is found.?

According to the presumed consent system, persons who do not wish to donate their organs needed to register the phrase "Non-donor of organs and tissues" in their ID card or driver's license. Thus, every Brazilian who did not express their unwillingness to donate their organs while alive used to be considered a potential donor.

The presumed consent system did not find support in Brazilian society; therefore, Provisional Measure 1718 of 06 October 1998 was enacted providing for mandatory family consultation prior to donation by presumed donors, which already occurred in practice. Thus, Law 10.211, published in March 2001, established the need for informed consent prior to donation. The law states that "the removal of tissues, organs and body parts of deceased persons for transplantation or other therapeutic purposes is subject to authorisation by the spouse or another relative of legal age, following direct or collateral family succession up to the second degree, expressed in a document signed by two witnesses present at moment of death verification." The Brazilian law is clear and requires family consent for the removal of organs and tissues for transplantation.

The technical regulation determining the minimum technical-sanitary criteria for the operation of eye tissue banks (BTOC) is the executive board resolution RDC/ANVISA \#6 of September 30,2008, while the operation of skeletal muscle tissue banks is regulated by RDC/ANVISA \#220 of December 27, 2006.

Eye banks are responsible for harvesting, processing, evaluating, classifying, storing, and distributing eye tissues and must meet the legal requirements for their establishment and operation. ${ }^{8}$

\section{Cornea donation process}

Identification of potential donors is done through passive reporting and active searching. Every deceased patient aged 280 years is a potential donor of eye tissue for transplantation up to 6 hours after cardiac arrest, or 24 hours if the entire body is kept in a cold room; brain death is not necessary. The donor's eyelids should be kept closed to prevent the corneas from drying due to light exposure. The procedure can be performed outside the hospital environment (e.g., a morgue or the donor's home). The maximum time for extracorporeal preservation of corneas is 14 days. Notification of potential donors is required by law and should be reported to the $\mathrm{CNCDO}$ and the eye bank operating in the region. ${ }^{7,9}$ 
RDC $67^{10}$ establishes a legal requirement to collect eye tissues only within 6 hours after death. The protocol of the Eye Bank Association of America (EBAA) ${ }^{11,12}$ does not establish a time period for collecting corneas after death; instead, it states that ice packs should be used in the orbital area over the eyelids to extend the time limit for enucleation, thus attempting to reduce damage to eye tissues by toxins that form naturally after death.

Because of the legal time limit for collecting corneas in Brazil, many corneas are rejected for donation, thus increasing the waiting time for a corneal transplant. The six-hour limit to collect the cornea is often not sufficient. This time limit is often exceeded for various reasons; for example, the family is not always present at the time of death, or needs more time to consider and authorise the donation, and the collection team may not arrive in time due to logistical reasons.

Organisation for Organ Procurement (OPO), Organisation for Cornea Procurement (OPC): These are non-profit organisations working in partnership with CNCDOs on a regional basis to detect potential donors; they are composed of one or more hospitals in each region. These organisations perform active searches by visiting intensive care units, emergency rooms, and hospital morgues; visits are conducted by nurses or physicians. During the visit, the visiting professional must introduce him/ herself to the multidisciplinary team, explain the reason for their visit, the importance of their work and, whenever possible, provide information materials about the donation-transplantation process.

Hospital commission for organ and tissue donation for transplantation (CIHDOTT): These are internal committees established in each hospital to better organise the organ harvesting process, identify potential donors, interview families, and organise the interaction between the hospital and the respective CNCDO, which ultimately improves corneal harvesting both qualitatively and quantitatively.

In the donation-transplantation process, a set of interrelated actions and procedures is followed that turn a potential donor into an effective donor; the process is concluded with transplantation (Figure 1).

\section{Corneal transplantation in Rio de Janeiro State}

Donation-Transplantation Process

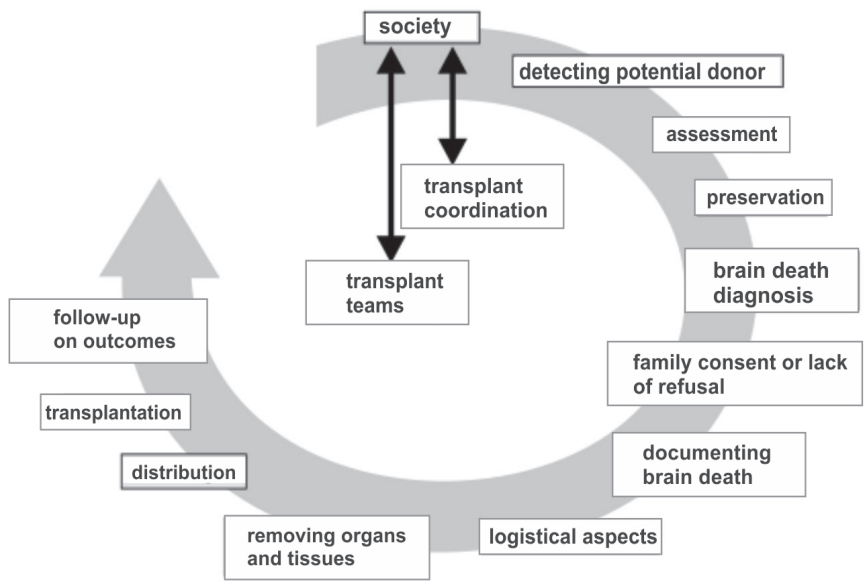

Source: Adapted from Martinez R, et al. Organ Procurement in Spain: the National Organization of Transplant. In: Touraine JL, et al., editors. Organ shortage: the solutions. Dordrecht: Kluwer Academic; 1995. p.167-77.

Figure 1. Steps of the donation-transplantation process
Between 2006 and 2009, on average 74 corneal transplants were performed each year in Rio de Janeiro (Figure 2). During this period, for more than a year there were no eye banks operating in the state, therefore corneas had to come from other states or from abroad.

In early 2010 the state transplant programme (PET) was

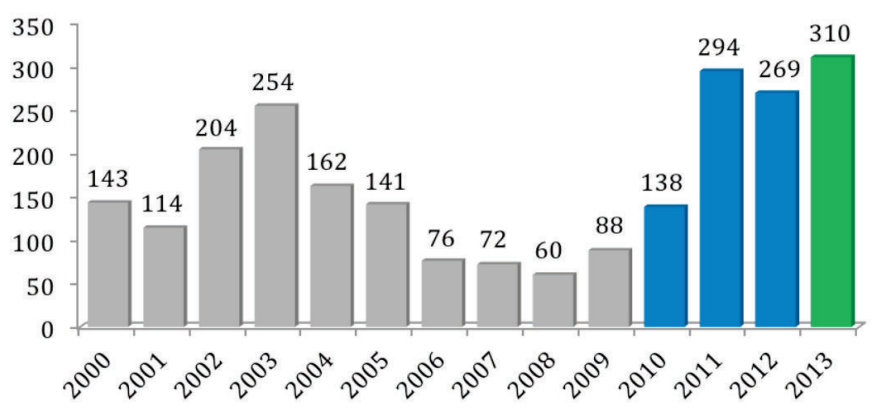

Source: State Transplant Programme (PET).

Figure 2. Corneal transplants in the Rio de Janeiro State.

created. Its mission is to coordinate the organ and tissue donation and transplantation process in the state, act as a CNCDO, and establish the transplant policy.

The PET promotes the continuing education of physicians, nurses, psychologists, and social workers and provides courses on each step of the process: detection of donors; legal issues; family interviews; and organisation, management, and communication aspects. A hotline (155) and a website (www.transplante.rj.gov.br) have been created to inform the population. The website has a communication channel and other services related to transplants in the state.

The PET actively assists in implementing and organising OPOs/OPCs and the CIHDOTT in the state; this should improve the notification of potential donors and increase the number of harvested corneas, thus meeting the demands of the waiting list in a more flexible manner.

Since 2010 there was an increase in the number of donors per million population ( $\mathrm{pmp}$ ), which improved from 8.7 (2009) to 15 (2012), surpassing countries such as Germany, Denmark, Sweden, Australia, and Japan.

In August 2010 the Pedro Sélmo Thiesen (Volta Redonda Eye Bank) eye tissue bank opened in St. John the Baptist Hospital (HSJB), $130 \mathrm{~km}$ from the city of Rio de Janeiro. This increased the number of harvested and transplanted corneas, but the waiting time for a corneal transplant in the state remained high.

In order to improve the logistics and increase corneal harvesting, reducing waiting times in the state, the PET and the National Institute of Traumatology and Orthopaedics (INTO) developed a project to build a public Eye Bank in the metropolitan area of Rio de Janeiro.

\section{Creation of the Rio de Janeiro Eye Bank - INTO}

INTO's Eye Bank officially began its activities in September 2013 after approval by the Ministry of Health. It is located in the facilities of the Multi-tissue Transplant Unit (DITMT-INTO) and follows national and international standards, i.e. the National Technical Regulation for Transplants and Executive Board Resolution RDC $67^{10}$ of the National Health Surveillance Agency (ANVISA) for harvesting and preserving corneas, based on the standards of the Eye Bank Association of 
America (EBAA) ${ }^{11}$

INTO's eye bank is responsible for harvesting, removing, and processing corneal tissues. Together with CNCDO-RJ/PET it removes and processes corneas in almost all hospitals of the Metropolitan and Northern regions of Rio de Janeiro State.

The better organisation of eye banks led to improvements in corneal harvesting and preservation. Thanks to the careful selection of donated tissues through specular microscopy and endothelial cell counts, improved understanding of corneal physiology, use of adjustable sutures, and new surgical techniques, corneal transplantation is now a routine procedure with high rates of success. ${ }^{13}$

INTO has a quality control system accredited by the Joint Commission on Accreditation of Healthcare Organisations, which accredits hospitals based on good medical practice and strict safety and efficiency standards.

Human tissues suitable for transplantation include the cornea, sclera, bone tissue, cartilage, tendon, meniscus, fascia, heart valves, skin, vessels, and amniotic membrane. INTO's musculoskeletal tissues bank and eye bank are currently part of the only fully-operational Tissue Bank (ocular and musculoskeletal tissues) in the country. ${ }^{14}[$ Personal communication, ANVISA].

INTO also plans to create a skin and heart valve bank, benefiting patients from various medical specialties.

\section{Discussion}

The United States of America (USA) is the country performing the highest number of corneal transplants in absolute terms. The number of transplants in Brazil is considerably lower, but it is increasing significantly each year (Tables 1 and 2). US patients pay for the processing and transplantation costs either out of pocket or through health insurance plans, with the exception of very poor patients who benefit from government programmes (Medicare and Medicaid).
According to the SNT, Brazil currently has the largest public organ and tissue transplant programme in the world ${ }^{14}$. The public health system finances more than $95 \%$ of transplants performed in Brazil and also partially subsidises immunosuppressive drugs for all patients.

National organ and tissue transplant policy guidelines establish the free donation of organs and tissues, beneficence toward recipients, and non-maleficence. They also establish guarantees and rights for patients who need a transplant and regulate the entire care network by accrediting and reaccrediting operating teams and institutions. The transplant policy is in line with Laws 8080/1990 and 8142/1990 which regulate the functioning of the Brazilian public health system (SUS). ${ }^{15}$

In Brazil the entire cost of the family interview, harvesting, and processing by the eye bank is paid by the public health system (SUS); under no circumstances does the patient pay for a cornea. If the patient chooses to undergo surgery outside the accredited SUS network, he/she can use their health insurance or pay for surgery out of pocket.

Corneal transplants represent about $75 \%$ of all organ transplants in Brazil. ${ }^{16}$ The number of corneal transplants is 73.3 per million population (pmp), which is near the goal of 90 transplants pmp needed to reduce waiting times to zero.

However, waiting times and the number of patients registered for a corneal transplant vary substantially among the 27 states. The Federal District and the states of São Paulo, Goiás, and Pernambuco lead the country with more than 100 transplants pmp. However, six states still perform fewer than 30 transplants pmp: Bahia, Pará, Acre, Rio de Janeiro, Alagoas, and Maranhão. Another four states do not perform any transplants: Amapá, Rondônia, Roraima and Tocantins. ${ }^{17}$

Despite the growing number of corneal transplants in Brazil, regional differences still need to be resolved. The large number of transplants concentrated in a few states in comparison with other populous states of the Federation is worthy of note. Such discrepancy represents an unacceptable social injustice. While wealthy citizens can travel to other states to be included

Table 1

Comparative data on the activities of eye tissue banks in Brazil and the United States of America.

\begin{tabular}{lccc}
\hline Activities of eye tissue banks & Brazil 2011 & Brazil 2012 & EUA 2012 \\
\hline Donations & 14.665 & 15.004 & 116.990 \\
Number of corneas offered for transplantation & 15.983 & 16.505 & 68.681 \\
& & & $19.546^{*}$ \\
Number of corneal transplants & 14.696 & 15.281 & 46.684 \\
Number of tissues for research, teaching and training & 262 & 459 & 26.170 \\
\hline
\end{tabular}

United States of America (USA) * Total number of corneas submitted to foreign countries

Source: Brazilian Association of Organ Transplants (ABTO) and Eye Bank Association of America (EBAA).

Table 2

Number of corneal transplants in Brazil.

\begin{tabular}{lcccccccccccc}
\hline Year & $\mathbf{2 0 0 1}$ & $\mathbf{2 0 0 2}$ & $\mathbf{2 0 0 3}$ & $\mathbf{2 0 0 4}$ & $\mathbf{2 0 0 5}$ & $\mathbf{2 0 0 6}$ & $\mathbf{2 0 0 7}$ & $\mathbf{2 0 0 8}$ & $\mathbf{2 0 0 9}$ & $\mathbf{2 0 1 0}$ & $\mathbf{2 0 1 1}$ & $\mathbf{2 0 1 2}$ \\
\hline $\begin{array}{c}\text { Adsolute number } \\
\text { of transplants }\end{array}$ & 6.193 & 6.556 & 7.556 & 8.394 & 8.713 & 10.124 & 9.040 & 13.341 & 12.723 & 12.778 & 14.696 & 15.281 \\
\hline
\end{tabular}

Source: Brazilian Association of Organ Transplants (ABTO). 
in a shorter waiting list, disadvantaged patients need to wait for extremely long times for a corneal transplant. Ideally, corneal harvesting and transplantation should be performed equitably in all states, with surgery being provided by SUS to all citizens. ${ }^{18}$

The statistics mask an even more dramatic picture, as it is unlikely that in certain states there is not a single patient requiring corneal transplantation, and in remote regions there is probably an unmet demand resulting from difficulties in access to health care, which prevent patients from registering in transplant waiting lists.

In Brazil, only one out of eight potential donors is reported. ${ }^{19}$ Data from 2013 showed that the rate of reporting of potential donors was $46.0 \mathrm{pmp}$ in the state of Rio de Janeiro. This rate was above the national average, $53.1 \mathrm{pmp}$, but family refusal rates were still high $(50 \%){ }^{20}$

The family interview is one of the most complex steps in the cornea donation process, involving ethical, legal, and emotional aspects. Interviewing professionals need to be well prepared to clear any doubts, share feelings, and facilitate the donation process. Families need to be clearly informed about the entire donation process and its implications in order to make a coherent and autonomous decision.

The main obstacles include logistical problems such as an insufficient number of notifications and high rates of family refusals motivated by several factors, such as: a failure to understand the concept of brain death, fear of deforming the body after removal of the eyeball (enucleation), fear of organ trafficking, and lack of knowledge about the organ and tissue distribution and allocation system. ${ }^{21}$

There is evidence that the rates of consent for cornea donations are lower than for organs. A retrospective study conducted in the United States found that among approximately 10,000 deaths, $46.5 \%$ of approached families agreed to donate multiple organs, but only $23.5 \%$ agreed to donate corneas. ${ }^{22}$

The concerns and lack of understanding about the cornea donation process are usually not resolved simply with public awareness campaigns. Improved attitudes by health care professionals toward cornea donations might facilitate the donation-transplantation process through knowledge. Increasing the knowledge of health care professionals about organ donation and transplantation and training them to disseminate such information could help increase the number of donors.

Rio de Janeiro State has recently enacted Law 6584/13, which establishes that the families of deceased organ and tissue donors should be given priority in all state institutions, including police stations, technical and scientific bodies, hospitals, health centres, and funeral services. The law states that these institutions should post clearly visible signs in their facilities stating: "Priority given to families of organ and tissue donors".

In order to reduce waiting times to zero in the state of Rio de Janeiro, it is necessary to dynamically identify and solve the main problems facing harvesting teams; conduct corneal transplants in a timely manner in the public and private health systems; encourage cornea donations; stimulate corneal harvesting; identify the reasons why a greater number of transplants are not performed; and improve the utilisation rates of harvested tissues.

The current situation is the result of unequal preconditions rooted in the history of our society over the decades in which our social fabric developed. Our health care system is built collectively on a daily basis. It is both cause and effect of our socioeconomic and health inequalities, and it can thus be improved.
Organ and tissue donation and allocation is a difficult and delicate process that depends on popular trust in the system and the commitment of health care professionals to notifying deaths. Brazil performs the second largest number of transplants in the world; to consolidate this achievement, involvement of the Ministry of Health, state governments, and medical organisations throughout the entire donation and transplantation process is critical. ${ }^{5}$

\section{REFERÊNCIAS}

1. Whitcher JP, Srinivasan M, Upadhyay MP. Corneal blindness: a global perspective. Bull World Health Organ. 2001;79(3):214-21. Review.

2. Brasil. Ministério do Planejamento, Orçamento e Gestão. Instituto Brasileiro de Geografia e Estatística. Contas Nacionais [internet]. IBGE, Brasília (DF); 2010 [citado 2014 Jan 15]. Disponível em: http:/ /censo2010.ibge.gov.br

3. Kara-Junior N, Mourad PC, Espiìndola RF, AbilRuss HH. [Expectation and knowledge among patients with keratoplasty indication]. Rev Bras Oftalmol. 2011;70 (4):230-4. Portuguese.

4. Brasil. Ministério da Saúde. Secretaria de atenção a saúde. DATAUS. Cadastro nacional de estabelecimento em saúde [internet].DATASUS Brasília (DF); 2014 [citado 2013 Jan 15]. Disponível em: http:// cnes.datasus.gov.br

5. Associação Brasileira de Transplantes de Órgãos (ABTO). Disponiìvel em:http://www.abto.org.br

6. Brasil. Ministério do Planejamento, Orçamento e Gestão. Instituto Brasileiro de Geografia e Estatística. Contas regionais do Brasil [internet]. IBGE, Brasília (DF); 2005-2009 [citado 2014 Jan 15]. Disponível em: http://www.ibge.gov.br/home/estatistica/economia/ contasregionais/2009/contasregionais2009.pdf

7. Brasil. Ministério da Saúde. Portaria n. 3.407, de 5 de agosto de 1998. Aprova o Regulamento Técnico sobre as atividades de transplantes e dispõe sobre a Coordenação Nacional de Transplantes [internet]. Brasília (DF); 1998 Ago 6 [citado 2014 Jan 15]. Disponível em: http:/ /dtr2001.saude.gov.br/sas/dsra/port3407.htm

8. Hilgert CV, Sato EH. [Management performance of eye banks and its impact on those organizations results]. Rev Bras Oftalmol. 2012;71(1):28-35. Portuguese.

9. Brasil. Ministério da Saúde. Lei no 9.434 de fevereiro de 1997. Dispõe sobre a remoção de órgãos, tecidos e partes do corpo humano para fins de transplante, e dá outras providências [internet]. Diário Oficial da União Federativa do Brasil, Brasília (DF); 1997 Fev 4[citado 2014 Jan 15]. Disponível em: http://www.planalto.gov.br/ccivil_03/leis/ 19434.htm

10. Brasil. Ministério da Saúde. Agência Nacional de Vigilância Sanitária. Resolução RDC n. 67, de 30 de setembro de 2008. Dispõe sobre o Regulamento Técnico para o Funcionamento de Bancos de Tecidos Oculares de origem humana [internet]. Diário Oficial da União Federativa do Brasil, Brasiìlia (DF); 1997 Fev 4[citado 2014 Jan 15]. Disponível em: http://www.google.com.br/ portal.anvisa.gov.br.

11. Donor Maintenance Protocol; D1.600 Ocular Tissue Donor Maintenance. Procedures Manual [Internet]. Eye Bank Association of America (EBAA) 2008. [cited 2014 Mar 23]. Available from:. http:// www.restoresight.org/.

12. Rosenwasser GO, Nicholson WJ. Introduction to eye banking: a handbook and atlas: a guide to eye bank techniques, corneal evaluation, and grading. [S.1.]; c2003. Donor maintenance.p. 25-9.

13. Barbosa AP, Almeida Juìnior GC, Teixeira MF, Barbosa JC. [Evaluation of penetrating keratoplasty indications in inner part of the São Paulo state]. Rev Bras Oftalmol. 2012;71(6):353-7. Portuguese.

14. Zeschau A, Balestrin IG, Stock RA, Bonamigo EL. [Indications of 
keratoplasty: a retrospective study in a University Hospital]. Rev Bras Oftalmol. 2013;72(5):316-20. Portuguese.

15. Lei n ${ }^{\circ} 8.080$, de 19 de Setembro de 1990. Dispõe sobre as condições para a promoção, proteção e recuperação da saúde, a organização e o funcionamento dos serviços correspondentes e dá outras providências [Internet]. Brasília(DF): Casa Civil:1990. [citado 2013 Out 7]. Disponível em: http://www.planalto.gov.br/ccivil_03/leis/18080.htm

16. Disponível em: Brasil. Tribunal de Contas da União. Relatório de avaliação de programa: Programa Doação, Captação e Transplante de Órgãos e Tecidos / Tribunal de Contas da União ; Relator Ministro Marcos Vinicius Vilaça. - Brasília:TCU, Secretaria de Fiscalização e Avaliação de Programas de Governo, 2006.134 p. : il. Acórdão n 562/ 2006 - TCU - Plenário.

17. Registro Brasileiro de Transplantes. Associação Brasileira de Transplante de Órgãos. Dados numéricos da doação de órgãos e transplantes realizados por estado e instituição no período: janeiro/ setembro 2013 [internet]. São Paulo: ABTO; 2013 [citado 2014 Jan 15]. Disponível em:http://www.abto.org.br/abtov03/Upload/file/RBT/ 2013/ParcialRBT-3TRI(1).pdf

18. Conselho Brasileiro de Oftalmologia. Banco de olhos, transplante de córnea. Rio de Janeiro: Cultura Médica; 2008; p. 5-13.
19. Marinho A, Cardoso SS, Almeida VV. [Geographic disparities in organ transplantation in Brazill. Cad Sauìde Puìb.2010;26(4):786-96. Portuguese.

20. Dimensionamento dos Transplantes no Brasil e em cada Estado (20052012). [Internet]. RBT. 2012;18(4):1-96. [citado 2014 Mar 23]. Disponível em: http://www.abto.org.br/abtov03/Upload/file/RBT/ 2012/RBTdimensionamento2012.pdf

21. Barcellos FC, Araujo CL, da Costa JD. Organ donation: a populationbased study. Clin Transplant. 2005;19(1):33-7.

22. Lawlor M, Dobbins T, Thomas KA, Billson F. Consent for corneal donation: the effect of age of the deceased, registered intent and which family member is asked about donation. $\mathrm{Br} \mathrm{J}$ Ophthalmol. 2006;90(11):1383-5.

\section{Corresponding author:}

Gustavo Bonfadini

Rua Figueiredo Magalhães, 394 Copacabana, Rio de Janeiro/RJ, Brazil, CEP: 22031-010

E-mail: bonfadini.oftalmologia@gmail.com 